\title{
An environmentally friendly and productive process for bioethanol production from potato waste
}

\author{
Fangzhong Wang ${ }^{1,2}$, Yi Jiang ${ }^{1}$, Wei Guo ${ }^{1}$, Kangle Niu ${ }^{1}$, Ruiqing Zhang ${ }^{1}$, Shaoli Hou ${ }^{1}$, Mingyu Wang ${ }^{1}$, Yong Yi ${ }^{3}$, \\ Changxiong Zhu ${ }^{3}$, Chunjiang Jia ${ }^{2}$ and Xu Fang ${ }^{1 *}$
}

\begin{abstract}
Background: China is the largest sweet potato producer and exporter in the world. Sweet potato residues (SPRs) separated after extracting starch account for more than $10 \%$ of the total dry matter of sweet potatoes. In China, more than 2 million tons of SPRs cannot be utilized, and the unutilized SPRs are perishable and result in environmental pollution. Thus, an environmentally friendly and highly efficient process for bioethanol production from SPRs should be developed.

Results: The swelling behaviour of cellulose causes high-gravity sweet potato residues to be recalcitrant to enzymatic hydrolysis. Cellulase plays a major role in viscosity reduction and glucose production. In contrast, pectinase has a minor role in viscosity reduction but acts as a "helper protein" to assist cellulase in liberating glucose, especially at low cellulase activity levels. In total, 153.46 and $168.13 \mathrm{~g} / \mathrm{L}$ glucose were produced from high-gravity SPRs with cellulase and a mixture of cellulase and pectinase, respectively. These hydrolysates were fermented to form 73.37 and $79.00 \mathrm{~g} / \mathrm{L}$ ethanol, respectively. Each kilogram of dry SPR was converted to form 209.62 and $225.71 \mathrm{~g}$ of ethanol, respectively.

Conclusion: The processes described in this study have an enormous potential for industrial production of bioethanol because they are environmentally friendly, highly productive, economic with low cost, and can be easily manipulated.
\end{abstract}

Keywords: Sweet potato residues, Cellulase, Pectinase, Bioethanol, Viscosity reduction, Glucose production

\section{Background}

The extensive use of fossil fuels has stimulated economic development and has promoted the progress of human civilization since the twentieth century. However, problems involving the rapid depletion of fossil fuels have caused serious concern. The incremental demand for an energy supply has led to a rapid reduction in fossil fuels and the subsequent world energy crisis [1]. The greenhouse effect caused by the massive combustion of fossil fuels has gradually destabilized the world ecosystem and human social systems [2]. Consequently, the need

\footnotetext{
${ }^{*}$ Correspondence: fangxu@sdu.edu.cn

${ }^{1}$ State Key Laboratory of Microbial Technology, School of Life Science,

Shandong University, Jinan, Shandong, China

Full list of author information is available at the end of the article
}

for sustainable and environmentally friendly alternative energies has been recognized by society $[1,3]$. Because of its unique advantages over other renewable energies, bioethanol produced from agricultural or industrial waste has received special attention. The use of renewable and carbon neutral bioethanol is considered an effective strategy to counter the greenhouse effect [4]. The chemical intermediates that accompany bioethanol production can be produced by biorefineries [5], and bioethanol is compatible with the current supply of liquid fuels [6]. Therefore, bioethanol is one of the most promising alternatives to fossil fuels that can ensure energy security and address environmental pollution problems $[7,8]$. Many new technologies for bioethanol production from various wastes are being extensively studied, while 
environmentally friendly processes are being constantly improved [9-13].

China is the largest sweet potato producer and exporter in the world [14], with more than 71 million tons of sweet potatoes being produced each year. Sweet potatoes are one of the important raw materials for starch preparation. Sweet potato residues (SPRs) separated after extracting starch account for more than $10 \%$ of the total dry matter of sweet potatoes. In China, more than 2 million tons of SPRs cannot be utilized, perhaps owing to their high viscosity. Moreover, the unutilized SPRs are perishable, and release methane as they turn rancid because they contain abundant polysaccharides and proteins [15-18]. The influence of methane, the second-most common greenhouse gas, on climate change is more than 25 times greater than that of carbon dioxide over a 100-year period [19]. Therefore, unutilized SPRs pose a serious problem of environmental pollution. Recently, acid-catalysed hydrolysis methods of releasing sugar from potato wastes were reported for bioethanol production $[20,21]$. However, these processes increase the discharge of industrial waste water [22] and raise costs because they require investment in corrosionresistant equipment and production of fermentation inhibitors [1]. Thus, these technologies have limited industrial application. Therefore, an efficient and environmentally friendly method that uses enzymatic hydrolysis should be developed for bioethanol production from potato waste.

Enzyme-catalysed hydrolysis usually occurs in lower substrate contents owing to the high viscosity of potato waste, leading to poor efficiency and high energy consumption [23, 24]. Energy consumption is a major part of the cost of ethanol production [25]. High-gravity fermentation technology could produce very high ethanol titres, which could decrease energy consumption for ethanol distillation and waste distillation treatment [26, 27]. Therefore, bioethanol production based on corn and wheat mashes has received significant attention [28, 29]. However, the feasibility of bioethanol production based on highly concentrated SPRs has rarely been reported.

In the present study, the feasibility of converting highgravity SPRs into bioethanol was studied. The performance of different enzyme systems during high-gravity SPRs hydrolysis was investigated. Then, the possible roles of cellulase and pectinase during enzymatic hydrolysis of highgravity SPRs were investigated. Finally, $79.00 \mathrm{~g} / \mathrm{L}$ ethanol was produced from enzymatic hydrolysates by Saccharomyces cerevisiae. Our findings may be used as a reference for industrial production of bioethanol based on SPRs.

\section{Results and discussion}

\section{Chemical component analysis of SPRs}

SPRs are starch-containing industrial waste. Their chemical composition was investigated to evaluate their potential for SPR-based bioethanol production. Dry SPR is composed of $30.01 \pm 1.27 \%$ (w/w, dry weight) starch, $29.29 \pm 3.17 \%$ cellulose, $13.79 \pm 1.12 \%$ pectin, $4.16 \pm 0.50 \%$ lignin and $1.98 \pm 1.58 \%$ ash. Each kilogram of dry SPRs can release $658.96 \pm 41.74$ g glucose, $178.34 \pm 14.50$ g galacturonic acid, $80.28 \pm 3.66$ g galactose and $10.07 \pm 1.83 \mathrm{~g}$ xylose according to the National Renewable Energy Laboratory protocols (see "Methods" section). It is obvious that the hemicellulose content is lower in SPRs.

Meyer et al. [30] reported that galactose substitutes for side chains of galacturonan, which is the backbone of pectin in dicotyledonous plants. Sweet potato is a type of dicotyledonous plant. The contents of galactose and galacturonic acid were relatively high in the SPRs, which may suggest that there is plenty of pectin in the SPRs. The pectin is composed of galacturonan with highly branched galactose. Starch comprises $64.81 \pm 1.59 \%$ of sweet potato, and the total content of cellulose and pectin is less than $13 \%$. Therefore, more than half of the starch is extracted by the starch-processing industry, and the contents of cellulose and pectin are apparently increased in the SPRs. Cellulose and pectin are crosslinked polymers that can exhibit swelling behaviour when exposed to solvent agents [31-34]. It is speculated that cellulose and pectin in SPRs could form a complex network to limit the mobility of enzyme molecules. Furthermore, the viscosity of SPRs becomes higher as substrate concentration increases, leading to the lower mobility of enzyme. Therefore, the contents of cellulose and pectin have a great influence on bioethanol production. The impacts of lignin and ash on enzyme hydrolysis and ethanol production can be neglected owing to their low contents. After starch was partially extracted from sweet potato, $658.96 \mathrm{~g}$ of glucose was still released from each $\mathrm{kg}$ of SPRs. These results suggest that SPRs are potential raw material sources for glucose and bioethanol production. A scheme of over-process for glucose or bioethanol production from SPRs was proposed in Fig. 1.

\section{Assessment of the hydrolysis performance of different enzyme systems on high-gravity SPRs}

The high-gravity SPRs were directly hydrolysed by $\alpha$-amylase and $\alpha$-glucosidase, but their viscosity was sharply increased, and the amount of released glucose was relatively low.

To develop an efficient and environmentally friendly process, we investigated the Filter paperase (FPase), pectinase and $\alpha$-amylase activities of various enzyme systems, which have the potential to degrade three SPR components: starch, cellulose and pectin. The Penicillium oxalicum JUA10-1, Trichoderma reesei $\mathrm{T} 1$ and $T$. reesei TX enzyme systems exhibited higher specific cellulase 


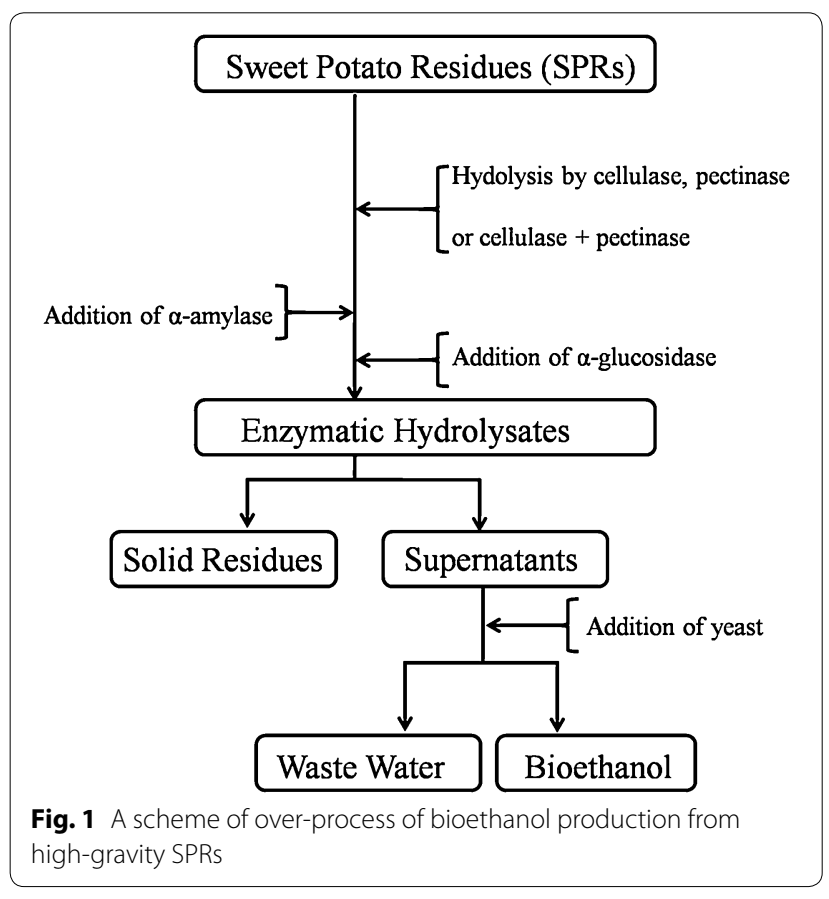

activities and lower specific pectinase and $\alpha$-amylase activities than enzymes derived from commercial pectinase and Aspergillus niger (Table 1). The hydrolysis efficiencies of these enzymes on high-gravity SPRs were evaluated for two parameters, namely viscosity change and glucose production. As shown in Fig. 2a, the viscosities of SPRs without or mixed with pectinase or enzymes (10 mg of soluble protein/g dry SPRs) derived from $A$. niger were increased, while those of the $P$. oxalicum JUA10-1, T. reesei $\mathrm{T} 1$ and $T$. reesei $\mathrm{TX}$ enzyme systems were considerably reduced. Furthermore, the glucan conversions of the $P$. oxalicum JUA10-1, T. reesei T1 and T. reesei TX enzyme systems were higher than those of pectinase or $A$. niger (Fig. 2b). Therefore, there may be a correlation between the amount of released glucose and the viscosity reduction of a reaction system. It is reported that cellulose fibre diameter could increase sevenfold in amine oxide/water systems [35], and the reconstituted cellulose could adsorb $338 \mathrm{~mL}$ water per $100 \mathrm{~g}$ of sample

Table 1 The comparisons of the specific activities of enzymes derived from different enzymatic systems

\begin{tabular}{llcc}
\hline Specific activity (U/mg) & FPase & Pectinase & a-amylase \\
\hline P. oxalicum JUA10-1 & $0.60 \pm 0.02$ & $13.97 \pm 1.33$ & $0.04 \pm 0.01$ \\
T. reeseiT1 & $0.41 \pm 0.02$ & $1.23 \pm 0.02$ & $0.02 \pm 0.00$ \\
Commercial pectinase & $0.01 \pm 0.00$ & $529.79 \pm 36.01$ & $0.07 \pm 0.00$ \\
A. niger & $0.05 \pm 0.00$ & $2.12 \pm 0.12$ & $0.07 \pm 0.01$ \\
T. reeseiTX & $0.28 \pm 0.02$ & $0.81 \pm 0.02$ & $0.01 \pm 0.00$ \\
\hline
\end{tabular}

[36]. In combination with the enzymatic activities shown in Table 1, these results suggest that the high viscosity of high-gravity SPRs results from cellulose swelling, not starch and pectin. One possible reason for higher glucose production is that the viscosity reduction of a reaction system leads to improved mobility of $\alpha$-amylase and $\alpha$-glucosidase, releasing more glucose from starch, not just from cellulose hydrolysis.

\section{The roles of cellulase and pectinase during enzymatic hydrolysis of high-gravity SPRs}

As shown in Fig. 2b, glucan conversion of $P$. oxalicum JUA10-1 is the highest. The specific FPase and pectinase activities in $P$. oxalicum JUA10-1 were much higher than those in $T$. reesei $\mathrm{T} 1$ or $T$. reesei $\mathrm{TX}$ enzyme systems (Table 1). However, we were interested to determine which enzymes are mainly responsible for glucose release. Therefore, equal amounts of FPase activity were added to the reactions containing high-gravity SPRs, after which it was found that there was no significant difference between the glucan conversions of $T$. reesei TX and $P$. oxalicum JUA10-1 (Fig. 3), although the specific pectinase activity of $P$. oxalicum JUA10-1 was 17-fold higher than that of $T$. reesei TX. The glucan conversion reached $62.37 \%$, and the glucose concentration in the reaction system was $153.46 \mathrm{~g} / \mathrm{L}$ (Table 2). Thus, it was suggested that FPase activity greatly contributes to the liberation of glucose from SPRs.

As shown in Fig. 3, the amount of released glucose was not increased as the activities of cellulase derived from the $P$. oxalicum JUA10-1 or T. reesei TX enzyme systems exceeded $6 \mathrm{FPU} / \mathrm{g}$ dry SPRs. One possible reason is that the pectinase activity of the enzyme system derived from P. oxalicum JUA10-1 or T. reesei TX is too low to adequately degrade pectin that still limits cellulase accessibility to cellulose. Therefore, the role of pectinase should be explored for further improvement of glucan conversion. The enzyme solutions derived from $T$. reesei $\mathrm{TX}$ with commercial pectinase were chosen for further study because the enzyme system of $T$. reesei TX has the low specific pectinase activity (Table 1 ).

The viscosity was dramatically increased when commercial pectinase was used, even with the addition of 10,000 PGU/g dry SPRs (Fig. 4a). In contrast, the viscosity was decreased when the activity of cellulase derived from $T$. reesei TX was more than 4 FPU/g dry SPRs in the reaction system (Fig. 4b). These results suggest that cellulase, but not pectinase, plays a major role in viscosity reduction. As shown in Fig. 4c, there is no significant change when pectinase is mixed into the reaction system. The rates and degrees of viscosity reduction were lower than those of $4 \mathrm{FPU} / \mathrm{g}$ dry SPRs. Thus, there may be no synergistic effect between cellulase and pectinase on viscosity reduction. 

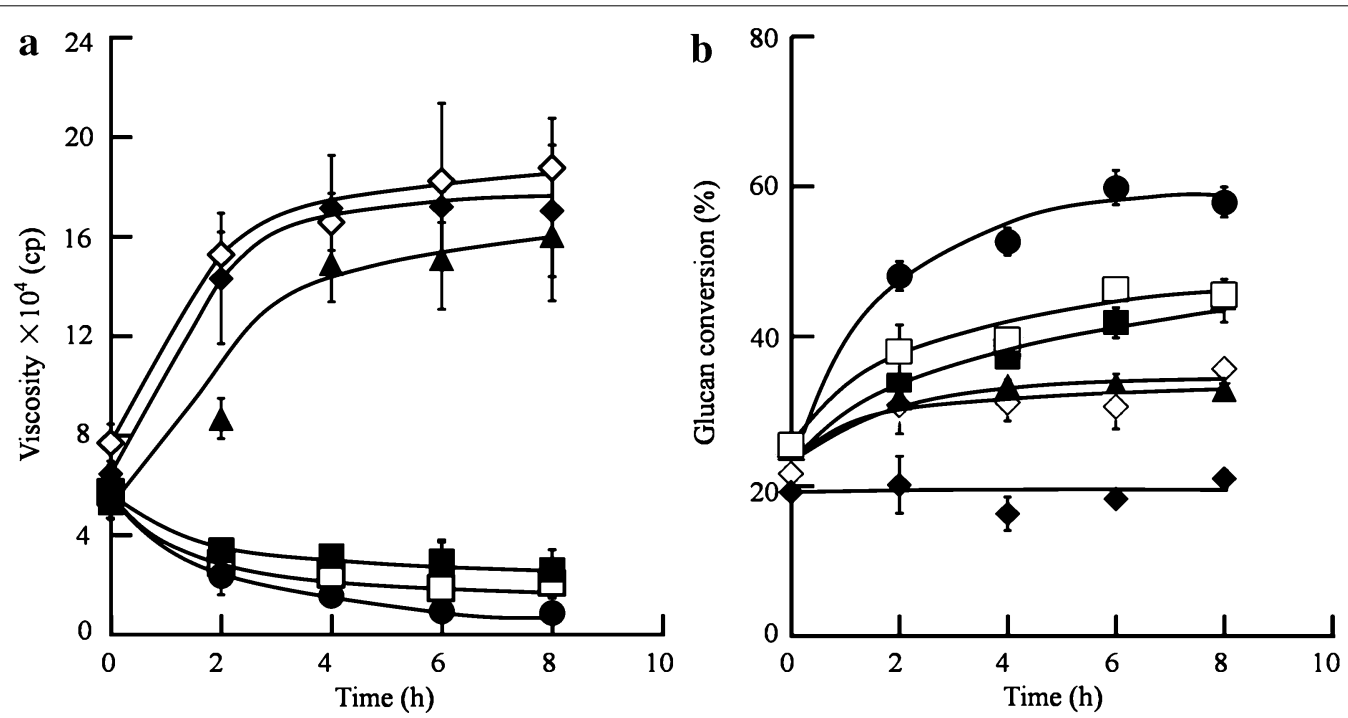

Fig. 2 The viscosity changes (a) and the glucan conversions of high-gravity SPRs (b) during enzymatic hydrolysis. All the reactions were performed at $45^{\circ} \mathrm{C}$ and $200 \mathrm{rpm}$ for $8 \mathrm{~h}$ with an initial pH of 4.8. The concentration of SPRs in reaction system was $36 \%(\mathrm{w} / \mathrm{v})$. Three independent replicates were performed. Solid diamonds represent the control, hollow diamonds represent commercial pectinase, solid triangles represent enzymes derived from A. niger, solid squares represent T. reesei TX, hollow squares represent T. reeseiT1, and solid circles represent $P$. oxalicum JUA10-1

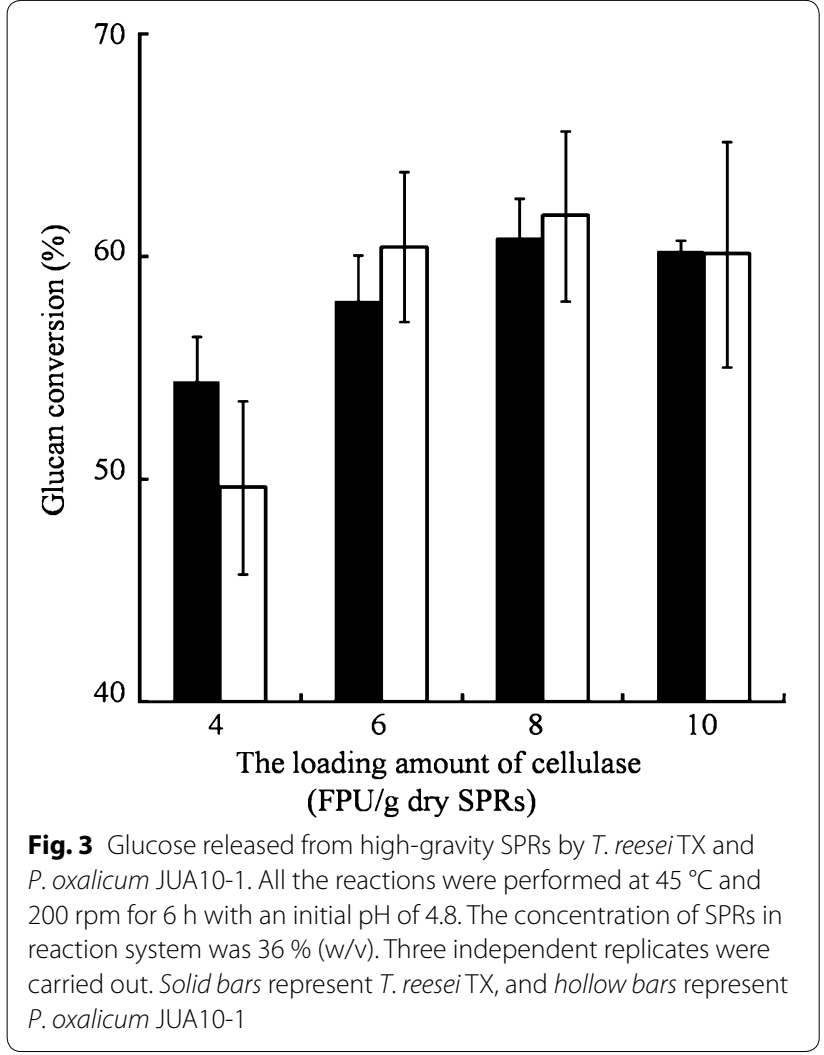

These findings seem to be in conflict with reports on viscosity reduction of high-gravity potato mash [37]. Celluclast $1.5 \mathrm{~L}$ contributed little to viscosity reduction, but pectin-degrading enzymatic solutions such as Pectinex Ultra SP-L or Viscozyme L could effectively decrease the viscosity of high-gravity potato mash [37]. However, there are also reports that cellulase performed better than pectinase in viscosity reduction of high concentrations of raw materials containing cellulose and pectin [38-40]. The results in this study support the latter viewpoint. The swelling behaviours of starch, cellulose and pectin depend on the ratio of crystalline and amorphous regions and reaction conditions [34, 36, 41-43]. Therefore, the conflicting results may be resulting from the ratio of cellulose and pectin, the structural disparity of cellulose and pectin, the conditions for viscosity reduction, etc.

There was no significant change $(\mathrm{p}>0.05, \mathrm{n}=3)$ on the glucan conversion without or with addition of pectinase (Additional file 1). It was suggested that pectinase plays a minor role in the glucan conversion of SPRs. When the loading amount of cellulase was more than $4 \mathrm{FPU} / \mathrm{g}$ dry SPRs, the viscosity of the reaction system was considerably reduced, and the glucan conversion was significantly improved ( $\mathrm{p}<0.05, \mathrm{n}=3$ ) (Figs. 4c, 5). It was suggested that cellulase plays a major role in degrading SPRs. The glucan conversion of cellulase mixed with commercial pectinase was significantly higher than that with only the addition of 2 FPU/g dry SPRs ( $<0.05, \mathrm{n}=3$ ). Furthermore, the amount of released glucose was comparable to that achieved with the addition of 6 FPU/g dry SPRs at a considerably reduced total protein load. When the enzyme of $2 \mathrm{FPU} / \mathrm{g}$ dry SPRs + 1000 PGU/g dry SPRs was loaded, the total amount of protein loading $(50.2 \mathrm{mg})$ was nearly 
Table 2 Comparison of different processes using potato waste materials to produce ethanol

\begin{tabular}{|c|c|c|c|c|c|c|c|c|}
\hline Raw materials & $\begin{array}{l}\text { Substrate } \\
\text { concentration } \\
(w / v)\end{array}$ & $\begin{array}{l}\text { Pretreatment } \\
\text { method }\end{array}$ & $\begin{array}{l}\text { Glucose } \\
\text { concentration } \\
(\mathrm{g} / \mathrm{L})\end{array}$ & $\begin{array}{l}\text { Ethanol } \\
\text { concentration } \\
\text { (g/L) }\end{array}$ & $\begin{array}{l}\text { Glucan con- } \\
\text { version (\%) }\end{array}$ & $\begin{array}{l}\text { Glucose } \\
\text { to ethanol } \\
\text { conversion } \\
(\%)\end{array}$ & $\begin{array}{l}\text { Ethanol yield } \\
\text { (g/g, dry } \\
\text { weight) }\end{array}$ & Reference \\
\hline $\begin{array}{l}\text { Sweet potato } \\
\text { residues }\end{array}$ & $36 \%$ & $\begin{array}{l}\text { Enzymatic } \\
\text { hydrolysis }\end{array}$ & $168.13 \pm 2.62$ & $79.00 \pm 0.87$ & $68.34 \pm 1.07$ & $67.16 \pm 0.74$ & $0.23 \pm 0.00$ & This study \\
\hline $\begin{array}{l}\text { Sweet potato } \\
\text { residues }\end{array}$ & $36 \%$ & $\begin{array}{l}\text { Enzymatic } \\
\text { hydrolysis }^{b}\end{array}$ & $153.46 \pm 2.01$ & $73.37 \pm 1.87$ & $62.37 \pm 0.82$ & $62.37 \pm 1.59$ & $0.21 \pm 0.01$ & This study \\
\hline Potato pulp & $30 \%$ & $\begin{array}{l}\text { Hydrothermal } \\
\text { pretreat- } \\
\text { ment and } \\
\text { enzymatic } \\
\text { pretreat- } \\
\text { ment }^{c}\end{array}$ & 114 & Less than 60 & 68 & Less than 68 & Less than 0.2 & {$[48]$} \\
\hline $\begin{array}{l}\text { Potato peel } \\
\text { waste }\end{array}$ & $2 \%$ & $\begin{array}{l}\text { Enzymatic } \\
\text { hydrolysis }^{d}\end{array}$ & $18.48 \pm 0.65$ & $7.50 \pm 0.28$ & - & - & - & {$[23]$} \\
\hline $\begin{array}{l}\text { Waste potato } \\
\text { mash }\end{array}$ & - & $\begin{array}{l}\text { Physical meth- } \\
\text { od }^{\text {e }}\end{array}$ & Less than 80 & 35 & - & - & - & {$[24]$} \\
\hline $\begin{array}{l}\text { Potato } \\
\text { peel + sub- } \\
\text { standard } \\
\text { mash }\end{array}$ & $1: 1$ & $\begin{array}{l}\text { Enzymatic } \\
\text { hydrolysis }^{f}\end{array}$ & - & $48.6 \pm 1.3$ & - & 42.5 & 0.19 & {$[57]$} \\
\hline $\begin{array}{l}\text { Potato tuber } \\
\text { mash }\end{array}$ & $1: 1$ & $\begin{array}{l}\text { Acid-catalysed } \\
\text { hydrolysis }\end{array}$ & 100 & 32.9 & - & - & - & {$[20]$} \\
\hline $\begin{array}{l}\text { Potato peel } \\
\text { waste }\end{array}$ & $4 \%$ & $\begin{array}{l}\text { Acid-catalysed } \\
\text { hydrolysis }^{h}\end{array}$ & 18.15 & 6.97 & - & - & - & {$[23]$} \\
\hline $\begin{array}{l}\text { Potato starch } \\
\text { residue } \\
\text { stream }\end{array}$ & - & $\begin{array}{c}\text { Acid-catalysed } \\
\text { hydrolysis }^{i}\end{array}$ & 18.9 & $5.62 \pm 0.21$ & - & - & - & {$[21]$} \\
\hline \multicolumn{9}{|c|}{ a $4 \mathrm{FPU} / \mathrm{g}$ dry SPRs $+1000 \mathrm{PGU} / \mathrm{g}$ dry SPRs, $45^{\circ} \mathrm{C}$ for $6 \mathrm{~h}$, cellulase from T. reesei TX, pectinase was generously provided by Qingdao Vland Biotech Inc } \\
\hline \multicolumn{9}{|c|}{${ }^{\mathrm{C}}$ Hot water pretreatment, $121^{\circ} \mathrm{C}$ for $20 \mathrm{~min}, 5 \mathrm{FPU} / \mathrm{g}$ dry weight, $50^{\circ} \mathrm{C}$ for $48 \mathrm{~h}$, enzyme from A. cellulolyticus } \\
\hline \multicolumn{9}{|c|}{$\begin{array}{l}\text { d } 0.12 \mathrm{U} / \mathrm{g} \text { dry weight at } 85^{\circ} \mathrm{C} \text { for } 1 \mathrm{~h} \text {, enzyme from Termamyl } 120 \mathrm{~L} \text {, then } 12 \mathrm{U} / \mathrm{g} \text { dry weight at } 44^{\circ} \mathrm{C} \text { for } 2.5 \mathrm{~h} \text {, enzyme from Viscozyme, and finally, } 1 \mathrm{~g} \text { Celluclast per g } \\
\text { dry weight at } 50^{\circ} \mathrm{C} \text { for } 2 \mathrm{~h}\end{array}$} \\
\hline \multicolumn{9}{|c|}{ e Agitation at $120 \mathrm{rpm}$ for $3 \mathrm{~h}$ at a temperature chosen by the design based on a preliminary study } \\
\hline \multicolumn{9}{|c|}{ f The amount of enzyme, consisting of a-amylase + Pectinase + Enzyme complex, is $0.1 \%$. They were incubated at $50{ }^{\circ} \mathrm{C}$ for $21 \mathrm{~h}$} \\
\hline \multicolumn{9}{|c|}{ g $60 \mathrm{~min}$ in $1 \mathrm{M} \mathrm{HCl}$ at $100^{\circ} \mathrm{C}$} \\
\hline \multicolumn{9}{|c|}{ h $0.5 \mathrm{M} \mathrm{HCl}, 121^{\circ} \mathrm{C}$ for $15 \mathrm{~min}$} \\
\hline $60 \min$ in $1 \% \mathrm{H}_{2}$ & $\mathrm{O}_{4}$ at $100^{\circ} \mathrm{C}$ & & & & & & & \\
\hline
\end{tabular}

half of the amount achieved when using the 6 FPU/g dry SPRs $(115.7 \mathrm{mg})$. Therefore, the total amount of protein loading was reduced approximately twofold. The addition of cellulase mixed with pectinase could significantly improve glucan conversion more than that achieved with only the addition of 4 FPU/g dry SPRs $(\mathrm{p}<0.05, \mathrm{n}=3$ ). The glucan conversion of cellulase (4 FPU/g dry SPRs) mixed with the pectinase (above 1000 PGU/g dry SPRs) was significantly higher than that achieved when using only 6 FPU/g dry SPRs $(\mathrm{p}<0.05, \mathrm{n}=3)$. Moreover, glucan conversion was enhanced when cellulase $(6 \mathrm{FPU} / \mathrm{g}$ dry SPRs) mixed with pectinase solutions was used. The addition of commercial pectinase into low concentration of cellulase solutions could greatly improve glucan conversions. Pectinase could clear the barriers, such as pectin, which intertwine cellulose to improve cellulase motion on cellulose fibres. Therefore, pectinase acts as a "helper protein" to assist cellulase to degrade cellulose during the hydrolysis of high-gravity sweet potato residues, especially at low cellulase activity levels.

As mentioned above, the synergistic action of cellulase and pectinase was observed, and pectinase is a "helper protein" during high-gravity sweet potato residues hydrolysis. Therefore, the optimum concentration of pectinase in the mixture enzyme system depends on the loading amount of cellulase.

It was reported that cellulase contributes more to starch liberation than pectinase during cassava pulp hydrolysis [44]. The concerted action of cellulolytic enzymes and pectinase was observed when pretreated 


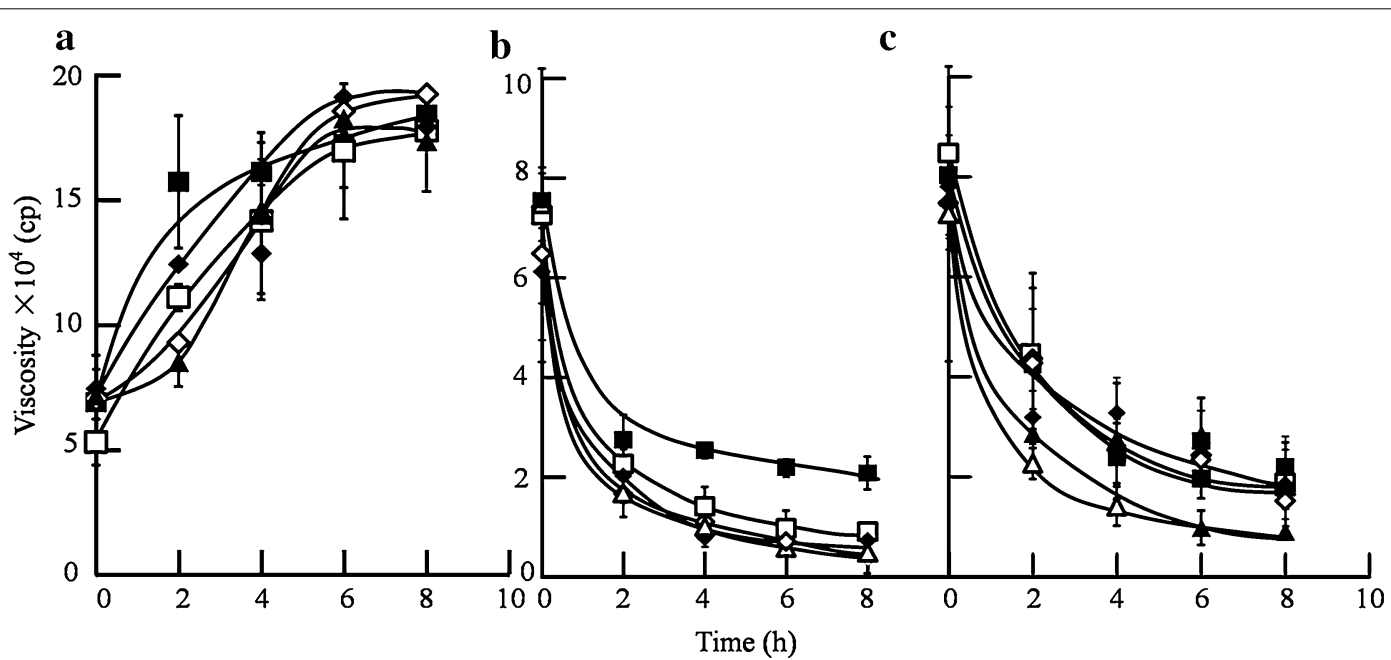

Fig. 4 Viscosity change of high-gravity SPRs when pectinase $(\mathbf{a})$, cellulase $(\mathbf{b})$ and mixtures $(\mathbf{c})$ were used. All the reactions were performed at $45^{\circ} \mathrm{C}$ and $200 \mathrm{rpm}$ for $8 \mathrm{~h}$ with an initial pH of 4.8. The concentration of SPRs in reaction system was $36 \%(\mathrm{w} / \mathrm{v})$. Three independent replicates were carried out. a Solid squares represent the control, hollow squares represent 500 PGU/g dry SPRs, solid diamonds represent 1000 PGU/g dry SPRs, hollow diamonds represent 5000 PGU/g dry SPRs and solid triangles represent 10,000 PGU/g dry SPRs. b Solid squares represent 2 FPU/g dry SPRs, hollow squares represent $4 \mathrm{FPU} / \mathrm{g}$ dry SPRs, solid diamonds represent $6 \mathrm{FPU} / \mathrm{g}$ dry SPRs, hollow diamonds represent $8 \mathrm{FPU} / \mathrm{g}$ dry SPRs, and hollow triangles represent 10 FPU/g dry SPRs. c Solid squares represent 2 FPU/g dry SPRs; hollow squares represent 2 FPU/g dry SPRs + 500 PGU/g dry SPRs; solid diamonds represent $2 \mathrm{FPU} / \mathrm{g}$ dry SPRs + $1000 \mathrm{PGU} / \mathrm{g}$ dry SPRs; hollow diamonds represent $2 \mathrm{FPU} / \mathrm{g}$ dry SPRs + $2500 \mathrm{PGU} / \mathrm{g}$ dry SPRs; solid triangles represent 2 FPU/g dry SPRs + 5000 PGU/g dry SPRs; and hollow triangles represent 4 FPU/g dry SPRs

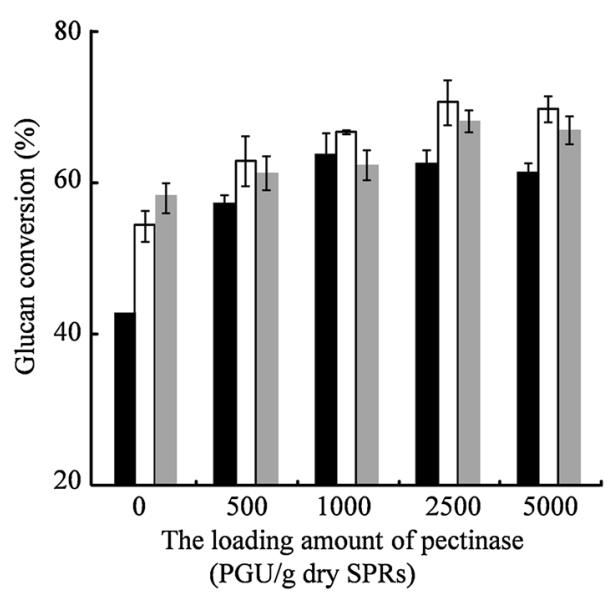

Fig. 5 Glucose released from high-gravity SPRs when the mixtures of cellulase + pectinase were used. All the reactions were performed at $45^{\circ} \mathrm{C}$ and $200 \mathrm{rpm}$ for $6 \mathrm{~h}$ with an initial pH of 4.8. The concentration of SPRs in reaction system was $36 \%(\mathrm{w} / \mathrm{v})$. Three independent replicates were carried out. Black bars represent 2 FPU/g dry SPRs with various PGU/g dry SPRs, hollow bars represent 4 FPU/g dry SPRs with various PGU/g dry SPRs, and grey bars represent $6 \mathrm{FPU} / \mathrm{g}$ dry SPRs with various $P G U / g$ dry SPRs

corn stover was hydrolysed, and their mixture reduced half of the loading amount of soluble protein [45]. These reports are consistent with the results in the present study. There are many reports on the synergistic effects of cellulase and accessory proteins on the stimulation of lignocellulolytic hydrolysis. For example, xylanase and lytic polysaccharide monooxygenase can enhance the hydrolysis efficiency of cellulase on high-gravity steampretreated poplar and corn stover [46]. GH10 endoxylanases and GH5 xyloglucanases had strong concerted effects with cellulase on the hydrolysis of pretreated lignocellulosic substrates, but the synergistic effects exhibited substrate dependence [47]. However, when 6 FPU/g dry SPRs was added, there was no significant synergistic effect of cellulase and pectinase on glucan conversion. The possible reason is as follows. Pectin and cellulose intertwine starch to restrict $\alpha$-amylase accessible in SPRs. When the concentration of cellulase is lower, pectinase could clear the barrier, such as pectin, to improve cellulase motion on cellulose fibres. Thus, glucan conversion is improved, and the synergistic action of cellulase and pectinase can be observed. However, more cellulosedegrading sites in SPRs are occupied by cellulase molecules with the increasing amount of cellulase loading. The complex network is quickly broken without further improvement in the motor ability of cellulase. Therefore, the concerted effect between cellulase and pectinase may not be obvious.

\section{Ethanol production from enzymatic hydrolysates by $S$. cerevisiae}

It is reported that the enzymatic hydrolysates of potato pulp could be fermented into ethanol without addition of 
any nitrogen source for improving efficiency [48]. Therefore, ethanol fermentations were directly performed with SPRs hydrolysed by $T$. reesei $\mathrm{TX}$ or $T$. reesei $\mathrm{TX}+$ pectinase enzymatic solutions without supplementing any source. The results are shown in Fig. 6. The glucose concentration with the enzyme from $T$. reesei TX was $153.46 \mathrm{~g} / \mathrm{L}$ after enzymatic hydrolysis, and the ethanol concentration reached $73.37 \mathrm{~g} / \mathrm{L}$. In addition, $5.76 \mathrm{~g} / \mathrm{L}$ of glucose was left after 72 -h fermentation by $S$. cerevisiae. When the enzyme of $T$. reese $i \mathrm{TX}+$ pectinase was added, the glucose concentration was $168.13 \mathrm{~g} / \mathrm{L}$ after enzymatic hydrolysis, ethanol was $79.00 \mathrm{~g} / \mathrm{L}$ and $2.46 \mathrm{~g} / \mathrm{L}$ of glucose remained. Therefore, almost the entire glucose was converted into ethanol without supplementing any nitrogen source.

\section{Comparison of different processes using potato waste materials to produce ethanol}

Table 2 contains a comparison of bioethanol production from potato waste materials by different processes reported in the literature. Although the acid-catalysed methods have relatively higher conversions [23], the glucose or ethanol concentrations are relatively lower. The drawbacks, such as fermentation inhibitor production, potential environmental pollution problems associated with waste disposal and the high cost of special equipment, are obvious $[1,49]$. Of the results listed in Table 2,

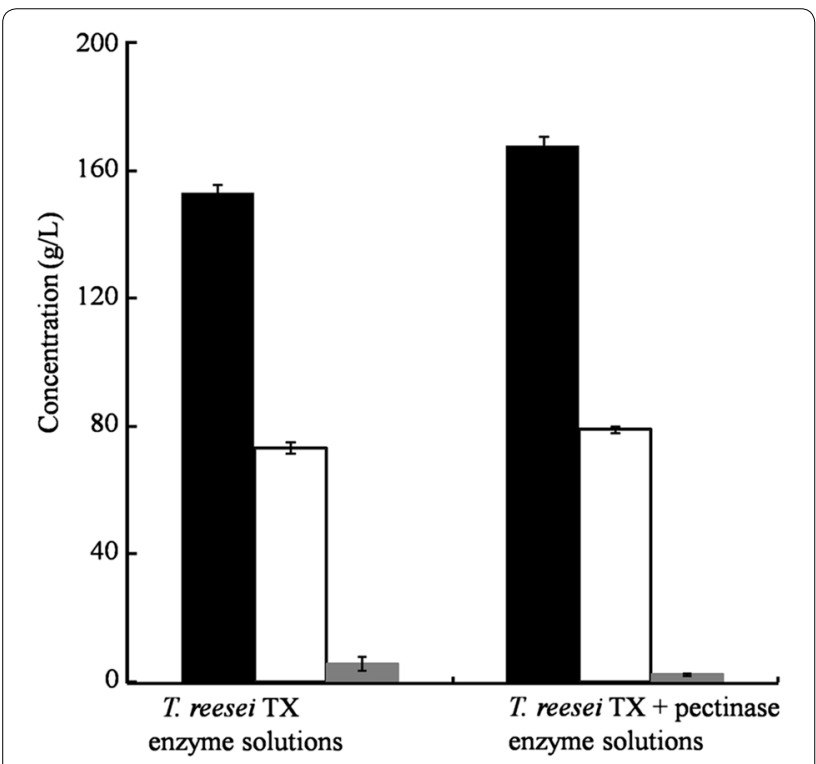

Fig. 6 Ethanol production from enzymatic hydrolysates by S. cerevisiae. The initial S. cerevisiae inoculation amount was $0.5 \%$. All the reactions were performed at $30^{\circ} \mathrm{C}$ for $72 \mathrm{~h}$. Three independent replicates were performed. Black bars represent glucose concentrations after enzymatic hydrolysis, hollow bars represent ethanol concentrations after fermentation by S. cerevisiae, and grey bars represent the remaining glucose concentrations after fermentation by $S$. cerevisiae the glucose and ethanol concentrations in this study are the highest among enzyme-catalysed methods. Furthermore, the processes are easily manipulated and are of low cost because they do not require further pretreatment or the addition of other enzymes, which react under different conditions, to produce ethanol. In addition, the amount of wastewater in these processes may be relatively lower among enzyme-catalysed methods because of high-gravity substrates. Therefore, they are ecofriendly, highly efficient, of low cost, and easily manipulated processes for bioethanol production.

\section{Conclusion}

The present results showed that $79.00 \mathrm{~g} / \mathrm{L}$ of ethanol could be obtained from high-gravity SPRs using enzyme hydrolysis. The swelling behaviour of cellulose was believed to cause high-gravity SPRs to be recalcitrant to enzymatic hydrolysis. Cellulase plays major roles in viscosity reduction and glucose production. Pectinase seems to contribute little to viscosity reduction but acts as a "helper protein" to assist cellulase in liberating glucose, especially at low cellulase activity levels. The concentrations of glucose and ethanol produced from potato wastes were the highest in this study. Compared with other processes, the processes described here have an enormous potential for industrial-scale production of bioethanol because they are environmentally friendly, highly productive, of low cost, and easily manipulated.

\section{Methods \\ Materials}

SPRs and high sugar tolerant instant dry yeast were provided by Shandong Bio Sunkeen Co., Ltd, Jining, Shandong, China. The cellulase solutions were produced by $P$. oxalicum JUA10-1, T. reesei T1, T. reesei TX and Aspergillus niger, which are laboratory-maintained filamentous fungi [6]. T. reesei TX was obtained as follows: the xylanase III gene (Genbank accession number: BAA89465.2) was replaced by $\beta$-glucosidase 1 ( $b g l 1$, Genbank accession number: KJ739789.1) derived from $A$. niger under the control of the T. reesei T1 xylanase III promoter. The methods for cellulase production were as described else [11]. The commercial pectinase solution was generously provided by Qingdao Vland Biotech, Qingdao, Shandong, China. The $\alpha$-amylase (Novozymes (China) Biotechnology Co., Ltd) and $\alpha$-glucosidase (Shandong Longda Bioproducts Co., Ltd) were generously provided by Jiang $\mathrm{Su}$ Lianhai Biological Technology Co., Ltd. Citric pectin, polygalacturonic acid, soluble starch, and $p$-nitrophenyl$\alpha^{-}{ }^{-}$-glucopyranoside were purchased from SigmaAldrich, St. Louis, MO, USA. Whatman No. 1 filter paper was purchased from Hangzhou Whatman-Xinhua Filter Paper, Hangzhou, Zhejiang, China. All other chemicals 
were bought from Sinopharm Chemical Reagent, Shanghai, China.

\section{Analytical methods}

FPase, pectinase, $\alpha$-amylase, and $\alpha$-glucosidase activities were measured as described elsewhere [50-52]. The protein concentration was assayed using the Lowry method [53]. For composition analysis of SPRs, glucose, xylose and galactose were produced according to the National Renewable Energy Laboratory protocols [54]. The content of glucose was determined as described elsewhere [6]. The contents of xylose and galactose were determined using a Dionex ICS 2500 system (Thermo Scientific, Waltham, MA, USA) with a CarboPac ${ }^{\mathrm{TM}}$ PA1 analytical column $(2 \times 250 \mathrm{~mm})$. The elution solution was a mixture of water and $400 \mathrm{mM} \mathrm{NaOH}$ at a volume ratio of 95:5. The production and measurement of galacturonic acid followed the protocols as previously described [55]. The pectin content was based on the released galacturonic acid. Ash and lignin were measured as described elsewhere [56]. Starch content was determined with the method described previously [48]. The cellulose content was determined by subtracting the starch content from the glucan content. Three independent replicates were performed.

\section{Viscosity measurement of SPRs during enzymatic hydrolysis}

Cellulase from P. oxalicum A10-1, T. reesei T1, T. reesei TX, commercial pectinase and their mixtures were added to SPRs in amounts corresponding to $10 \mathrm{mg}$ of soluble protein/g dry SPRs, and the viscosity change of these solutions was measured. The final SPR concentrations were adjusted to $36 \%$ by supplementing citric acid buffer $(10 \mathrm{mM}, \mathrm{pH} 4.8)$ in all viscosity tested assays. All the tubes were incubated in an oscillating machine (Type HYG-C, Suzhou Peiying Laboratory Equipment, Jiangsu, China) at $45^{\circ} \mathrm{C}$ and $200 \mathrm{rpm}$ for $8 \mathrm{~h}$. The viscosity change of SPRs was monitored every $2 \mathrm{~h}$ using a viscometer (Type LVDV-C, Brookfield Engineering Labs, Middleboro, MA, USA) equipped with an s64 rotor at a speed of $3 \mathrm{rpm}$. Three independent replicates were performed.

\section{Determination of glucose release from SPRs during enzymatic hydrolysis}

Cellulase from P. oxalicum A10-1, T. reesei T1, T. reesei $\mathrm{TX}$, commercial pectinase and their mixtures were added to SPRs in amounts corresponding to $10 \mathrm{mg}$ soluble protein/g dry SPRs, and the glucose released from the SPRs was measured. The final substrate SPRs were adjusted to $36 \%$ by supplementing citric acid buffer $(10 \mathrm{mM}, \mathrm{pH} 4.8)$ in all glucose production assays. All the tubes were incubated in an oscillating machine at $45^{\circ} \mathrm{C}$ and $200 \mathrm{rpm}$ for $8 \mathrm{~h}$. Subsequently, 53 units of $\alpha$-amylase were added and incubated at $90^{\circ} \mathrm{C}$ for $2 \mathrm{~h}$, and the reactions were cooled to $60{ }^{\circ} \mathrm{C}$ with the addition of 34 units of $\alpha$-glucosidase. The reaction systems were incubated for $6 \mathrm{~h}$ to obtain the maximum glucose release. The released glucose was measured by HPLC. The HPLC system (Hitachi, Tokyo, Japan) equipped with an Aminex HPX-87H column $(7.8 \times 300 \mathrm{~mm}, 9 \mu \mathrm{m}$ particle size, Bio-Rad Laboratories, Hercules, CA, USA) and an RI detector (Model L-2490, Hitachi, Tokyo, Japan) was used for glucose measurement. Separation was performed at a $0.5 \mathrm{~mL} / \mathrm{min}$ flow rate and at $45{ }^{\circ} \mathrm{C}$. The mobile phase was $1 \mathrm{mM} \mathrm{H}_{2} \mathrm{SO}_{4}$. The glucan conversion was calculated according to the follow equation:

$$
\text { Glucan conversion }=\frac{C g \times V g}{M \times W} \times 100,
$$

where $C g$ is the obtained glucose concentration $(\mathrm{g} / \mathrm{L})$; $\mathrm{Vg}$ is the volume of enzymatic hydrolysis (L); $M$ is the amount of dry SPRs (g); and $W$ is the maximum amount of glucose released from dry SPRs (\%). Three independent replicates were performed. Two-tailed Student's t tests were used for statistical analysis, and $\mathrm{p}<0.05$ was considered statistically significant.

\section{Ethanol production after enzymatic hydrolysis}

Cellulase from $T$. reesei TX, commercial pectinase and their mixtures were added to SPRs. The final substrate concentrations were adjusted to $36 \%$ by supplementing citric acid buffer $(10 \mathrm{mM}, \mathrm{pH} 4.8)$. All the tubes were incubated in an oscillating machine at $45{ }^{\circ} \mathrm{C}$ and $200 \mathrm{rpm}$ for $6 \mathrm{~h}$. Subsequently, 53 units of $\alpha$-amylase were added and incubated at $90^{\circ} \mathrm{C}$ for $2 \mathrm{~h}$. Next, the reactions were cooled to $60{ }^{\circ} \mathrm{C}$ with the addition of 34 units of $\alpha$-glucosidase. The reaction systems were incubated for $6 \mathrm{~h}$ to obtain the maximum glucose release. Approximately $1.4 \mathrm{~g}$ of high sugar tolerant instant dry yeast $(S$. cerevisiae; Sunkeen, China) was dissolved in $50 \mathrm{~mL}$ of solution containing $2 \%$ glucose at $30{ }^{\circ} \mathrm{C}$ for $1 \mathrm{~h}$. Then, $2 \mathrm{~mL}$ of the solution was inoculated into $30 \mathrm{~mL}$ of the SPR enzymatic hydrolysates. The fermentations were incubated at $30{ }^{\circ} \mathrm{C}$ for $72 \mathrm{~h}$. The HPLC system (Hitachi, Tokyo, Japan) equipped with an Aminex HPX-87H column $(7.8 \times 300$ mm, $9 \mu \mathrm{m}$ particle size, Bio-Rad Laboratories, Hercules, CA, USA) and an RI detector (Model L-2490, Hitachi, Tokyo, Japan) were used for glucose and ethanol measurement. The separation was performed at a $0.5 \mathrm{~mL} / \mathrm{min}$ flow rate and at $45^{\circ} \mathrm{C}$. The mobile phase was $1 \mathrm{mM} \mathrm{H}_{2} \mathrm{SO}_{4}$.

The ethanol yield and glucose conversion were calculated according to the following equations:

$$
\text { Ethanol yield }=\frac{C e \times V}{M} \times 100
$$


and

Glucose to ethanol conversion $=\frac{C e \times V}{M \times W \times 0.51} \times 100$,

where $\mathrm{Ce}$ is the ethanol concentration $(\mathrm{g} / \mathrm{L}) ; V$ is the fermentation volume (L); $M$ is the amount of dry SPRs (g); and $W$ is the maximum amount of glucose released from dry SPRs (\%). Three independent replicates were performed.

\section{Additional file}

Additional file 1. The change of glucan conversions of high-gravity SPRs when commercial pectinase solutions were added. All the reactions were performed at $45^{\circ} \mathrm{C}$ and $200 \mathrm{rpm}$ for $6 \mathrm{~h}$ with an initial pH of 4.8. The concentration of SPRs in reaction system was $36 \%(\mathrm{w} / \mathrm{v})$. Three independent replicates were carried out.

\section{Abbreviations}

SPRs: sweet potato resides; FPase: filter paperase; FPU: filter paperase unit; PGU: polygalacturonase unit.

\begin{abstract}
Authors' contributions
FW carried out the whole experiment, participated in the design of the experiment and drafted the manuscript. YJ participated in the chemical analysis of sweet potato residues and viscosity determination. WG participated in viscosity and glucose determination. KN participated in the enzymatic activity assays and ethanol determination. RZ participated in the ethanol production. $\mathrm{SH}$ performed the production of enzyme solutions. MW participated in the design of the experiment and performed the statistical analysis. YY and $C Z$ participated in the chemical analysis of sweet potato residues and helped to revise the manuscript, CJ participated in the design of the experiment and helped to revise the manuscript. XF conceived of the study, participated in the design of the experiment, analysed the data and revised the manuscript. All authors read and approved the final manuscript.
\end{abstract}

\section{Author details}

${ }^{1}$ State Key Laboratory of Microbial Technology, School of Life Science, Shandong University, Jinan, Shandong, China. ${ }^{2}$ School of Chemistry and Chemical Engineering, Shandong University, Jinan, Shandong, China. ${ }^{3}$ Shandong Bio Sunkeen Co., Ltd, Jining, Shandong, China.

\section{Acknowledgements}

We thank Miss Jingyan Zhang for providing commercial pectinase solutions. This work was supported by the National High-Technology Research and Development Program of China (No. 2014BAD02B07), the Scientific and Technology Project of Shandong Province (No. 2014CGZH1312), the National Natural Science Foundation of China (No. 31570040), and the Shandong Province Natural Science Foundation (No.ZR2013CM041). The funders do not take any part in the design of experiments, the collection and analysis of data, preparation of the manuscript, or the decision to publish.

\section{Completing interests}

There is no competing interest among authors. Parts of the content were protected by the Chinese patents ZL 201310384161.0.

Received: 1 December 2015 Accepted: 19 February 2016

Published online: 02 March 2016

\section{References}

1. Morais ARC, Lopes AMD, Bogel-Lukasik R. Carbon dioxide in biomass processing: contributions to the green biorefinery concept. Chem Rev. 2015;115:3-27.
2. Sathre R. Comparing the heat of combustion of fossil fuels to the heat accumulated by their life cycle greenhouse gases. Fuel. 2014;115:674-7.

3. Qiu HG, Sun LX, Huang JK, Rozelle S. Liquid biofuels in China: current status, government policies, and future opportunities and challenges. Renew Sust Energ Rev. 2012;16:3095-104.

4. Nigam PS, Singh A. Production of liquid biofuels from renewable resources. Prog Energ Combust. 2011;37:52-68.

5. Fernando S, Adhikari S, Chandrapal C, Murali N. Biorefineries: current status, challenges, and future direction. Energ Fuel. 2006;20:1727-37.

6. Wang M, Han L, Liu S, Zhao X, Wang J, Loh SK, et al. A Weibull statisticsbased lignocellulose saccharification model and a built-in parameter accurately predict lignocellulose hydrolysis performance. Biotechnol J. 2015;10:1424-33.

7. Goldemberg J. Ethanol for a sustainable energy future. Science. 2007;315:808-10.

8. Wang M, Li Z, Fang X, Wang L, Qu Y. Cellulolytic enzyme production and enzymatic hydrolysis for second-generation bioethanol production. Adv Biochem Eng Biot. 2012;128:1-24.

9. Belal EB. Bioethanol production from rice straw residues. Braz J Microbiol. 2013;44:225-34

10. Littlewood J, Wang L, Turnbull C, Murphy RJ. Techno-economic potential of bioethanol from bamboo in China. Biotechnol Biofuels. 2013;6:173.

11. Liu K, Lin X, Yue J, Li X, Fang X, Zhu M, et al. High concentration ethanol production from corncob residues by fed-batch strategy. Bioresour Technol. 2010;101:4952-8.

12. Ouellet M, Datta S, Dibble DC, Tamrakar PR, Benke PI, Li CL, et al. Impact of ionic liquid pretreated plant biomass on Saccharomyces cerevisiae growth and biofuel production. Green Chem. 2011;13:2743-9.

13. Nakashima K, Yamaguchi K, Taniguchi N, Arai S, Yamada R, Katahira S, et al. Direct bioethanol production from cellulose by the combination of cellulase-displaying yeast and ionic liquid pretreatment. Green Chem 2011;13:2948-53.

14. Wang MX, Shi Y, Xia XF, Li DL, Chen Q. Life-cycle energy efficiency and environmental impacts of bioethanol production from sweet potato. Bioresour Technol. 2013;133:285-92.

15. Mei X, MuTH, Han JJ. Composition and physicochemical properties of dietary fiber extracted from residues of 10 varieties of sweet potato by a sieving method. J Arg Food Chem. 2010;58:7305-10.

16. Zhang YY, Mu TH, Zhang M. Optimisation of acid extraction of pectin from sweet potato residues by response surface methodology and its antiproliferation effect on cancer cells. Int J Food Sci Tech. 2013;48:778-85.

17. Hao ZH, Wang DJ, Chen H, Sun JM, Xu YY. Sweet potato starch residue as starting material to prepare polyacrylonitrile adsorbent via SI-SET-LRP. J Arg Food Chem. 2014;62:1765-70.

18. Wu YS, Guo J, Yan GH, Wei DW, Ge FX, Jl Shang, et al. Studies on technique of producing glucose from sweet potato residues by enzymes. $J$ Agr Sci Tech. 2014;16:157-62.

19. Overview of greenhouse gases, United States Environmental Protection Agency. 2015. http://www3.epa.gov/climatechange/ghgemissions/ gases/ch4.html. Accessed 23 Nov 2015.

20. Tasic MB, Konstantinovic BV, Lazic ML, Veljkovic VB. The acid hydrolysis of potato tuber mash in bioethanol production. Biochem Eng J. 2009;43:208-11.

21. Hashem M, Darwish SMI. Production of bioethanol and associated byproducts from potato starch residue stream by Saccharomyces cerevisiae. Biomass Bioenerg. 2010;34:953-9.

22. Zhang J, Wang MY, Gao MT, Fang X, Yano S, Qin SL, et al. Efficient acetonebutanol-ethanol production from corncob with a new pretreatment technology-wet disk milling. Bioenerg Res. 2013;6:35-43.

23. Arapoglou D, Varzakas T, Vlyssides A, Israilides C. Ethanol production from potato peel waste (PPW). Waste Manag. 2010;30:1898-902.

24. Izmirlioglu G, Demirci A. Ethanol production from waste potato mash by using Saccharomyces Cerevisiae. Appl Sci-Basel. 2012;2:738-53.

25. Bai FW, Anderson WA, Moo-Young M. Ethanol fermentation technologies from sugar and starch feedstocks. Biotechnol Adv. 2008;26:89-105.

26. Dziugan P, Balcerek M, Pielech-Przybylska K, Patelski P. Evaluation of the fermentation of high gravity thick sugar beet juice worts for efficient bioethanol production. Biotechnol Biofuels. 2013;6:158.

27. Liu CG, Wang N, Lin YH, Bai FW. Very high gravity ethanol fermentation by flocculating yeast under redox potential-controlled conditions. Biotechnol Biofuels. 2012;5:61. 
28. Devantier R, Pedersen S, Olsson L. Characterization of very high gravity ethanol fermentation of corn mash. Effect of glucoamylase dosage, presaccharification and yeast strain. Appl Microbiol Biot. 2005;68:622-9.

29. Thomas KC, Ingledew WM. Production of $21 \%(\mathrm{v} / \mathrm{V})$ ethanol by fermentation of very high gravity ( $\mathrm{VHG}$ ) wheat mashes. J Ind Microbiol Biot. 1992;10:61-8.

30. Meyer AS, Dam BR, Laerke HN. Enzymatic solubilization of a pectinaceous dietary fiber fraction from potato pulp: optimization of the fiber extraction process. Biochem Eng J. 2009;43:106-12.

31. Hans S. Swelling kinetics of polymers. J Macromol Sci. 1992;31:1-9.

32. Szepes A, Szabo-Revesz P, Mohnicke M. Water sorption behavior and swelling characteristics of starches subjected to dielectric heating. Pharm Dev Technol. 2007;12:555-61.

33. Botkova M, Suty S, Jablonsky M, Kucerkova L, Vrska M. Monitoring of kraft pulps swelling in water. Cell Chem Technol. 2013;47:95-102.

34. MacDougall AJ, Rigby NM, Ryden P, Tibbits CW, Ring SG. Swelling behavior of the tomato cell wall network. Biomacromolecules. 2001:2:450-5.

35. Chanzy H, Noe P, Paillet M, Smith P. Swelling and dissolution of cellulose in amine oxide/water systems. J Appl Polym Sci-Appl Polym Symp. 1983;37:239-59.

36. Andrews CM. Cellulose swelling measured by propanol-2 retention. Text Res J. 1963;33:330-2.

37. Srichuwong S, Fujiwara M, Wang XH, Seyama T, Shiroma R, Arakane M, et al. Simultaneous saccharification and fermentation (SSF) of very high gravity (VHG) potato mash for the production of ethanol. Biomass Bioenerg. 2009;33:890-8.

38. Huang YH, Jin YL, Zhao Y, Li YH, Fang Y, Zhang GH, et al. Viscosity reduction during fuel ethanol production by fresh sweet potato fermentation. Chin J Appl Environ Biol. 2012;18:661-6.

39. Foda YH, Mccollum JP. Viscosity as affected by various constituents of tomato juice. J Food Sci. 2006;35:333-8.

40. Koffi KE, Sims CA, Bates RP. Viscosity reduction and prevention of browning in the preparation of clarified banana juice. J Food Quality. 1991;14:209-18

41. Kalita RD, Nath Y, Ochubiojo ME, Buragohain AK. Extraction and characterization of microcrystalline cellulose from fodder grass; Setaria glauca (L) P. Beauv, and its potential as a drug delivery vehicle for isoniazid, a first line antituberculosis drug. Colloid Surface B. 2013;108:85-9.

42. lijima M, Hatakeyama T, Hatakeyama H. Swelling behaviour of calcium pectin hydrogels by thermomechanical analysis in water. Thermochim Acta. 2005;431:68-72.

43. Al-Muhtaseb AH, McMinn WAM. Magee TRA. Water sorption isotherms of starch powders. Part 2: thermodynamic characteristics. J Food Eng. 2004;62:135-42.

44. Sriroth K, Chollakup R, Chotineeranat S, Piyachomkwan K, Oates CG. Processing of cassava waste for improved biomass utilization. Bioresour Technol. 2000;71:63-9.
45. Berlin A, Maximenko V, Gilkes N, Saddler J. Optimization of enzyme complexes for lignocellulose hydrolysis. Biotechnol Bioeng. 2007;97:287-96.

46. Hu JG, Chandra R, Arantes V, Gourlay K, Van Dyk JS, Saddler JN. The addition of accessory enzymes enhances the hydrolytic performance of cellulase enzymes at high solid loadings. Bioresour Technol. 2015;186:149-53.

47. Hu JG, Arantes V, Pribowo A, Saddler JN. The synergistic action of accessory enzymes enhances the hydrolytic potential of a "cellulase mixture" but is highly substrate specific. Biotechnol Biofuels. 2013;6:112.

48. Gao MT, Yano S, Inoue H, Sakanishi K. Production of ethanol from potato pulp: investigation of the role of the enzyme from Acremonium cellulolyticus in conversion of potato pulp into ethanol. Process Biochem. 2012;47:2110-5

49. Taherzadeh MJ, Karimi K. Pretreatment of lignocellulosic wastes to improve ethanol and biogas production: a review. Int J Mol Sci. 2008;9:1621-51.

50. Achouri Y, Rider MH, Schaftingen EV, Robbi M. Cloning, sequencing and expression of rat liver 3-phosphoglycerate dehydrogenase. Biochem J. 1997;323(Pt 2):365-70.

51. Arellano-Carbajal F, Olmos-Soto J. Thermostable alpha-1,4- and alpha1,6-glucosidase enzymes from Bacillus sp isolated from a marine environment. World J Microb Biot. 2002;18:791-5.

52. Wang MY, Zhao QS, Yang JH, Jiang BJ, Wang FZ, Liu KM, et al. A mitogenactivated protein kinase Tmk3 participates in high osmolarity resistance, cell wall integrity integrity maintenance and cellulase production regulation in Trichoderma reesei. PLoS ONE. 2013;8:e72189.

53. Lowry OH, Rosebrough NJ, Farr AL, Randall RJ. Protein measurement with the Folin phenol reagent. J Biol Chem. 1951;193:265-75.

54. Wooley R, Ruth M, Sheehan J, Ibsen K, Majdeski H, Galvez A. Lignocellulosic biomass to ethanol process design and economics utilizing co-current dilute acid prehydrolysis and enzymatic hydrolysis current and futuristic scenarios (NREL/TP-580-26157). Golden: National Renewable Energy Lab; 1999.

55. Vazquez-Blanco ME, Vazquez-Oderiz ML, Lopez-Hernandez J, SimalLozano J, Romero-Rodriguez MA. HPLC determination of pectins in raspberries as galacturonic acid and optimization using forward optical scanning. J Chromatogr Sci. 1993;31:477-9.

56. Lu J, Li X, Yang R, Zhao J, Qu Y. Tween 40 pretreatment of unwashed water-insoluble solids of reed straw and corn stover pretreated with liquid hot water to obtain high concentrations of bioethanol. Biotechnol Biofuels. 2013:6:159.

57. Yamada S, Shinomiya N, Ohba K, Sekikawa M, Oda Y. Enzymatic hydrolysis and ethanol fermentation of by-products from potato processing plants. Food Sci Technol Res. 2009;15:653-8.

\section{Submit your next manuscript to BioMed Central and we will help you at every step:}

- We accept pre-submission inquiries

- Our selector tool helps you to find the most relevant journal

- We provide round the clock customer support

- Convenient online submission

- Thorough peer review

- Inclusion in PubMed and all major indexing services

- Maximum visibility for your research

Submit your manuscript at www.biomedcentral.com/submit

() Biomed Central 